\title{
Effects of selenium addition on minimally processed leafy vegetables grown in a floating system
}

\author{
Fernando Malorgio, ${ }^{a *}$ Karina E Diaz, ${ }^{b}$ Antonio Ferrante, ${ }^{c}$ \\ Anna Mensuali-Sodid and Beatrice Pezzarossa ${ }^{e}$
}

\begin{abstract}
BACKGROUND: In recent years the consumption of minimally processed leafy vegetables has been increasing. At the same time food quality and its effects on human health have become crucial issues. Since selenium (Se) is an important microelement due to its ability to defend human organisms against free radicals, we investigated the effects of Se on chicory and lettuce production, and assessed the feasibility of a floating system as a method of producing Se-enriched vegetables.

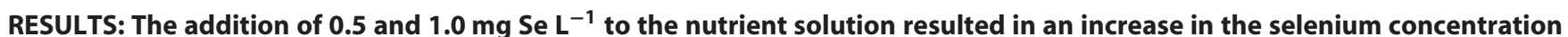
in the leaves, which had a positive effect on the plant yield. Selenium was generally effective in decreasing the production of ethylene and phenylalanine ammonia lyase (PAL) activity, even though a seasonal effect seemed to be present, consequently improving the quality of leafy vegetables and the shelf life in both species. The amount of Se accumulated in plants grown in the nutrient solution containing $0.5 \mathrm{mg} \mathrm{Se} \mathrm{kg}^{-1}$ could provide the rational Se intake for human nutrition in accordance with the recommended dietary allowance (RDA) guidelines.
\end{abstract}

CONCLUSIONS: The addition of Se in a nutrient solution can be a useful system for providing enriched leafy vegetables. The floating system can be used to modulate the availability of Se in nutrient solutions and to grow vegetables with the optimal Se content for human health.

(c) 2009 Society of Chemical Industry

Keywords: lettuce; chicory; ethylene; post-harvest; PAL activity

\section{INTRODUCTION}

In recent years, the production of minimally processed vegetables (MPVs), known as ready-to-eat products, has been increasing in order to satisfy the growing number of consumers. MPVs are more perishable than the original raw materials, due to the operations involved in the various processing steps. The physiology of MPVs is essentially that of wounded tissues with disorders that need to be minimised in order to obtain fresh-like quality products. ${ }^{1}$

Cutting activates several biochemical processes, which lead to increased ethylene production, responsible for a number of processes, including plant senescence, ${ }^{2}$ and tissue browning. ${ }^{3-5}$ Increased activity of phenylalanine ammonia lyase (PAL) has been observed before the appearance of browning in minimally processed lettuce and has been correlated with a decrease in shelf life. ${ }^{6}$

This study investigated the effects of the addition of antioxidant selenium on the shelf life and storage of leafy vegetables.

The post-harvest quality of fruits and vegetables, including those undergoing minimal processing, is traditionally defined in terms of external and internal parameters, such as visual appearance, microbial contamination, pesticide residuals, absence of disorders and diseases, vitamin and antioxidant content. However, the consumer choice is usually driven by the visual appearance, therefore during storage and in the distribution chain it is extremely important to preserve pigments such as chlorophyll, carotenoids and anthocyanins. ${ }^{7}$ These compounds, which are considered as phytonutrients, play an important role in the human diet and are responsible for the external quality of products, including leaf colour. Post-harvest chlorophyll degradation, leading to yellowing, is a symptom of the senescence process and a serious problem for green leafy vegetables. Plant senescence is a developmentally regulated process and is promoted by an accumulation of oxygen-containing radicals and their derivates, which can damage cells and tissues.

\footnotetext{
* Correspondence to: Fernando Malorgio, Dipartimento di Biologia delle Piante Agrarie, University of Pisa, viale delle Piagge, 23, 56100 Pisa, Italy. E-mail:fmalorgio@agr.unipi.it

a Dipartimento di Biologia delle Piante Agrarie, University of Pisa, Italy

b Horticultura, NACT-CRESCA y Programa Alimentos, Dep. Prod. Vegetal. Fac. Agronomía, Azul, Buenos Aires, Argentina

c Dip. Produzione Vegetale, University of Milan, Italy

d Scuola Superiore Sant'Anna, Pisa, Italy

e CNR, Istituto per lo Studio degli Ecosistemi, Pisa, Italy
} 
The reduction of peroxide free radicals and prostaglandin synthesis is catalysed by the enzyme glutathione peroxidase. Selenium (Se), a metalloid essential for the normal functioning of the human body, has been identified as a component of the enzyme glutathione peroxidase. ${ }^{8,9}$ On the basis of its antioxidative role, Se could delay plant senescence and decrease the post-harvest losses of agricultural plants. In the tomato, Se is effective in delaying fruit ripening through a decrease in ethylene biosynthesis. ${ }^{10}$ The addition of both sodium selenite and calcium chloride to irrigation water has been shown to increase mushroom resistance to post-harvest browning as well as enhancing the nutritional value of mushrooms. ${ }^{11} \mathrm{Se}$, in fact, is well known for its high potential in protecting biomembranes, eradicating free particles, inhibiting cancer, preventing senility and enhancing immunity.

The growing demand for MPVs has stimulated research to study new ways of improving the shelf-life quality of freshcut products, and of increasing the nutritional value of edible products. Vegetable and fruit products containing Se as an active microelement are considered as a physiological functional food, and the nutritional superiority of selenium enriched plant products has been assessed. ${ }^{12}$

The enrichment of vegetables with micronutrients, such as iron and selenium, which have beneficial effects on human health, has been evaluated in terms of enhancing the health properties of vegetables. ${ }^{13-18}$ Selenium can be supplemented to humans via an inorganic form, or through selenium-enriched products. The ability to increase the selenium content level in the human body, especially in the blood, is more effective for organic than for inorganic selenium. The biological utilisation ratio (i.e. the absorption ability) of organic selenium in plants is higher than inorganic selenium. Most of the organic selenium forms are less toxic for plants than inorganic forms and some, such as selenomethionine, can be accumulated in the human body. ${ }^{19}$ In general, crops containing less than $0.1 \mathrm{mg} \mathrm{kg}^{-1} \mathrm{DW}$ are considered Se deficient both for animal and human nutrition. Consumption of Se-enriched plants is a good way to supplement selenium because of the higher bioavailability of the organic forms. ${ }^{20}$

However, Se has a narrow range between essential and toxic threshold values, and the addition of high amounts of Se appears to have a pro-oxidant effect that reduces plant yield.

This study aimed to examine the effects of selenium on the growth, ethylene production, chlorophyll content and PAL activity in Chicorium intybus L. and Lactuca sativa L. var. Acephala plants grown in Se-enriched nutrient solutions. An assessment of the feasibility of the floating system as a valid method to produce Se-enriched plants was also evaluated.

\section{MATERIALS AND METHODS}

\section{Plant materials and treatments}

Three experiments were conducted in a heated greenhouse located in Pisa, Italy (latitude $43^{\circ} 40^{\prime} \mathrm{N}$ ), on chicory (Chicorium intybus L.) and green salad-bowl lettuce (Lactuca sativa L. var. Acephala) grown in hydroponic cultures. The floating system, utilised in many European Union countries to produce leafy vegetables, is a closed system which allows an appropriate discharge of the waste nutrient solution and a monitoring of the Se plant uptake, thus guaranteeing safe levels of Se in food plants.
Table 1. Chronological events and main climatic conditions of the cultivation cycle in the three experiments

\begin{tabular}{|cccc|} 
& \multicolumn{3}{c}{ Growing season } \\
\cline { 2 - 4 } & Autumn & Winter & Spring \\
\hline Sowing & 13 September & 20 December & 6 April \\
Harvest & 30 October & 1 February & 6 May \\
$\begin{array}{l}\text { Cycle length (days) } \\
\text { Daily global radiation } \\
\left(\mathrm{MJ} \mathrm{m}^{-2} \mathrm{~d}^{-1}\right)\end{array}$ & 46 & 42 & 30 \\
$\begin{array}{c}\text { Cumulative global } \\
\left.\text { radiation (MJ } \mathrm{m}^{-2}\right)\end{array}$ & 3.1 & 3.5 & 9.2 \\
$\begin{array}{c}\text { Mean air temperature } \\
\text { Mean }\end{array}$ & 145 & 148 & 507 \\
\hline
\end{tabular}

The first experiment was conducted in autumn, the second in winter, and the third in spring (Table 1). In all three experiments heating maintained the minimum night air temperature at $7-8^{\circ} \mathrm{C}$.

In each experiment a complete randomised block design was adopted with three replicates for each treatment. Each replicate consisted of a simple bed $2 \mathrm{~m}$ long, $1 \mathrm{~m}$ wide and $0.24 \mathrm{~m}$ deep, containing $450 \mathrm{~L}$ of nutrient solution. The seeds were sown in 260cell plug-trays measuring $0.32 \times 0.54 \mathrm{~m}$, and filled with perlite and vermiculite. Polystyrene plug-trays floated on a stagnant nutrient solution bed (floating raft system).

The nutrient solution contained $14 \mathrm{~N}-\mathrm{NO}_{3}, 1.25 \mathrm{P}, 10.7 \mathrm{~K}, 5 \mathrm{Ca}$, 1.6 Mg, 9.5 Na, 8.0 Cl, 2.7 S (concentrations are expressed in mmol $\mathrm{L}^{-1}$ ). Micronutrients were added at Hoagland's concentration (in $\mu \mathrm{mol} \mathrm{L}^{-1}: 40 \mathrm{~B}, 40 \mathrm{Fe}, 1 \mathrm{Cu}, 5 \mathrm{Zn}, 10 \mathrm{Mn}$ ). The nutrient solution was

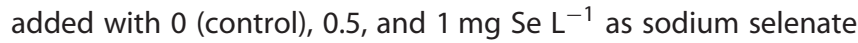
$\left(\mathrm{Na}_{2} \mathrm{SeO}_{4}\right)$.

When leaves reached commercial maturity, i.e. $6-10 \mathrm{~cm}$ in length, plants of each replicate were harvested, and the fresh weight (FW) of leaf material was determined. Plant yield was expressed as leaf biomass produced per square metre $\left(\mathrm{kg} \mathrm{m}^{-2}\right)$.

For each replicate, the detached leaves of half of the plants were oven dried at $50^{\circ} \mathrm{C}$ up to constant weight and the dry weight (DW) was recorded.

The detached leaves of the rest of the plants were washed with tap water, and slightly dried before storage. A leaf sample of $50 \mathrm{~g}$, for each treatment and for each replicate, was placed in a clear polyethylene semi-rectangular box with hinged lid, 100\% leak-proof ( $1 \mathrm{~L}$ capacity), and stored for 5 days at $4-5^{\circ} \mathrm{C}$ in dark conditions at $90 \% \mathrm{RH}, 340 \mathrm{ppm} \mathrm{CO}_{2}$ and $21 \% \mathrm{O}_{2}$.

\section{Chlorophyll content}

Total chlorophyll content, as well as chlorophyll $a$ and $b$, were determined at harvest and after a 5 day storage using Lichtenthaler's method. ${ }^{21}$ Foliar fresh tissue $(300 \mathrm{mg})$ was ground in liquid nitrogen and then added to $15 \mathrm{~mL}$ methanol $99 \%$ $\mathrm{v} / \mathrm{v}$. The samples were maintained in the dark for 2 days at $4{ }^{\circ} \mathrm{C}$ and the extracts were filtered and subsequently analysed using a spectrophotometer (Perkin-Elmer UV/VIS Lambda 1; Perkin-Elmer, Beaconsfield, Buckinghamshire, UK) at $665.2 \mathrm{~nm}$ and $652.4 \mathrm{~nm}$. The concentrations of chlorophyll a and chlorophyll b were calculated using the Welburn and Lichtenthaler formula. ${ }^{22}$

\section{Assay of phenylalanine ammonia lyase activity}

PAL activity was measured at harvest and after a 5 day storage of the plants in the winter and spring growing cycles. 
Leaf samples ( $1 \mathrm{~g}$ fresh tissue) were ground in a pre-chilled mortar and the powder was added to $3 \mathrm{~mL}$ of extraction buffer $\left(100 \mathrm{mmol} \mathrm{L}^{-1}\right.$ potassium borate $\mathrm{pH} 8.8,14 \mathrm{mmol} \mathrm{L}^{-1}$ 2-mercaptoethanol). The homogenate was centrifuged at $13000 \times$ $g$ for $30 \mathrm{~min}$ at $4{ }^{\circ} \mathrm{C}$, and $1 \mathrm{~mL}$ potassium borate and $200 \mu \mathrm{L} \mathrm{L}$ phenylalanine at $100 \mathrm{mmol} \mathrm{L}^{-1}$ were added at $100 \mu \mathrm{L}$ of the crude extract. The samples were incubated at $37^{\circ} \mathrm{C}$ for $60 \mathrm{~min}$ and the reactions were stopped by adding $250 \mu \mathrm{L}$ of $5 \mathrm{~mol} \mathrm{~L}^{-1} \mathrm{HCl}$. The trans-cinnamate produced by the PAL activity was determined spectrophotometrically at $290 \mathrm{~nm}^{23}$

\section{Ethylene production and accumulation}

Ethylene production by the leafy vegetables was measured at harvest and after a 5 day storage by enclosing leaves ( $25-45 \mathrm{mg}$ ) in airtight containers $(30 \mathrm{~mL})$. Leaves were randomly sampled from the storage boxes. Gas samples ( $2 \mathrm{~mL}$ each) were taken from the headspace of the containers with a hypodermic syringe after $1 \mathrm{~h}$ incubation at room temperature. The ethylene concentration in the sample was measured by gas chromatography (HP5890; Hewlett-Packard, Menlo Park, CA, USA) using a flame ionisation detector (FID), a stainless steel column ( 150 long $\times 0.4 \mathrm{~cm}$ diameter, packed with Hysep T), column and detector temperatures of $70^{\circ} \mathrm{C}$ and $350^{\circ} \mathrm{C}$, respectively, and nitrogen carrier gas at a flow rate of $30 \mathrm{~mL} \mathrm{~min}{ }^{-1} .{ }^{24}$ Quantification was performed against an external standard and the results were expressed on a fresh weight basis $\left(\mathrm{nL} \mathrm{g}{ }^{-1} \mathrm{FW} \mathrm{h}^{-1}\right.$ ).

The ethylene accumulation in the boxes was measured by taking 2- $\mathrm{mL}$ gas samples from the headspace of the boxes containing the leafy vegetables after storage for 1 and 5 days.

\section{Nitrate content}

Nitrate content was measured at harvest by a spectrophotometer using the salicylic-sulfuric acid methods. For each sample, $100 \mathrm{mg}$ of oven-dried ground leaf material were placed in a $30 \mathrm{~mL}$ icon glass with $10 \mathrm{~mL}$ of distilled water. Samples were placed in the shaking machine for $2 \mathrm{~h}$ at room temperature. After shaking, $10 \mathrm{~mL}$ of samples were centrifuged at $2160 \mathrm{~g}$ for $15 \mathrm{~min}$. The supernatant was recovered and $200 \mu \mathrm{L}$ were added to $800 \mu \mathrm{L}$ of $5 \%$ salicylic acid in sulfuric acid. The icon glass was placed in the stirring machine and $30 \mathrm{~mL} 1.5 \mathrm{~mol} \mathrm{~L}^{-1} \mathrm{NaOH}$ was slowly added. Usually, the samples were cooled to room temperature and spectrophotometer readings were performed at $410 \mathrm{~nm} .^{25}$ The nitrate content was calculated using calibration standards containing $0,1,2.5,5,7.5$ and $10 \mathrm{mmol} \mathrm{L}^{-1} \mathrm{KNO}_{3}$.

\section{Selenium content}

Total selenium content was determined at harvest in oven-dried ground leaf samples after digestion with nitric and perchloric acids and reduction by hydrochloric acid, following the method by Zasoski and Burau. ${ }^{26}$ The digests were analysed by hydride generation atomic absorption spectrophotometry (Varian VGA 77; Palo Alto, CA, USA).

\section{Statistical analysis}

The experimental design was completely randomised. Data were subjected to two-way analysis of variance (ANOVA). The means were separated using the least significant difference (LSD) test for $P=0.05$ or $P=0.01$.
Table 2. Plant yield $\left(\mathrm{kg} \mathrm{m}^{-2}\right)$ in lettuce and chicory plants subjected to different Se treatments, in different growing seasons

\begin{tabular}{|lccc|} 
& \multicolumn{3}{c}{ Growing season } \\
\cline { 2 - 4 } Se added $\left(\mathrm{mg} \mathrm{Se} \mathrm{L}^{-1}\right)$ & Autumn & Winter & Spring \\
\hline Lettuce & $2.45^{\mathrm{c}}$ & $0.95^{\mathrm{c}}$ & $4.11^{\mathrm{b}}$ \\
0 & $3.18^{\mathrm{b}}$ & $1.07^{\mathrm{b}}$ & $4.51^{\mathrm{a}}$ \\
0.5 & $3.56^{\mathrm{a}}$ & $1.21^{\mathrm{a}}$ & $4.47^{\mathrm{a}}$ \\
1 & & & \\
Chicory & & & \\
0 & $2.16^{\mathrm{d}}$ & $0.80^{\mathrm{d}}$ & $3.99^{\mathrm{b}}$ \\
0.5 & $3.21^{\mathrm{b}}$ & $1.19^{\mathrm{a}}$ & $3.95^{\mathrm{b}}$ \\
1 & $3.60^{\mathrm{a}}$ & $1.24^{\mathrm{a}}$ & $3.93^{\mathrm{b}}$ \\
Significance & & & \\
Se concentration $(A)$ & $*$ & $*$ & $\mathrm{NS}$ \\
Species $(B)$ & $\mathrm{NS}$ & $\mathrm{NS}$ & $*$ \\
$A \times B$ & $\mathrm{NS}$ & $*$ & $\mathrm{NS}$ \\
\hline
\end{tabular}

Each column was tested separately. Values followed by different letters differ significantly at the $5 \%$ level by the LSD test.

Significance level: $* P \leq 0.05$; NS $=$ not significant.

\section{RESULTS}

\section{Plant yield}

The highest values of leaf biomass per square metre were detected in the spring experiment, both in lettuce and in chicory (Table 2).

The addition of 0.5 and $1 \mathrm{mg} \mathrm{Se} \mathrm{L}^{-1}$ to the nutrient solution increased plant yield in both species and in all cultivation cycles. The effect of treatment was stronger in autumn compared to winter and spring. In spring, the addition of Se to chicory did not even induce any significant difference compared to the control (Table 2).

The dry matter production, expressed as $\mathrm{g} \mathrm{DW} 100 \mathrm{~g}^{-1} \mathrm{FW}$, did not change in relation to the cultivation cycle and it ranged between $4.5 \%$ and $4.8 \%$ both in lettuce and in chicory (data not shown).

\section{Chlorophyll content}

In all the experiments the chlorophyll content of lettuce and chicory leaves measured at harvest was unaffected by the Se treatments (Fig. 1).

After a 5 day storage the chlorophyll content of lettuce and chicory cultivated in autumn increased in the Se treated plants compared to controls (Fig. 1A), whereas in the winter experiment no differences were detected among treatments (Fig. 1B).

In the spring experiment the addition of Se significantly increased the chlorophyll content of chicory leaves, but not of lettuce, after vegetables had been stored for 5 days (Fig. 1C).

\section{PAL activity}

In the winter experiment the addition of Se decreased the enzyme activity detected at harvest in both plant species (Table 3 ). In

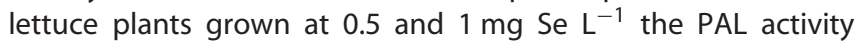
showed a reduction of $31 \%$ and $52 \%$, respectively, when compared to control plants. During storage no differences were observed among Se treatments. In chicory the addition of selenium decreased the enzyme activity by $30 \%$ and $44 \%$ in the 0.5 and $1 \mathrm{mgSe} \mathrm{kg}^{-1}$ treatments, respectively, when compared to controls. During storage the PAL activity increased in all treatments (Table 3). 

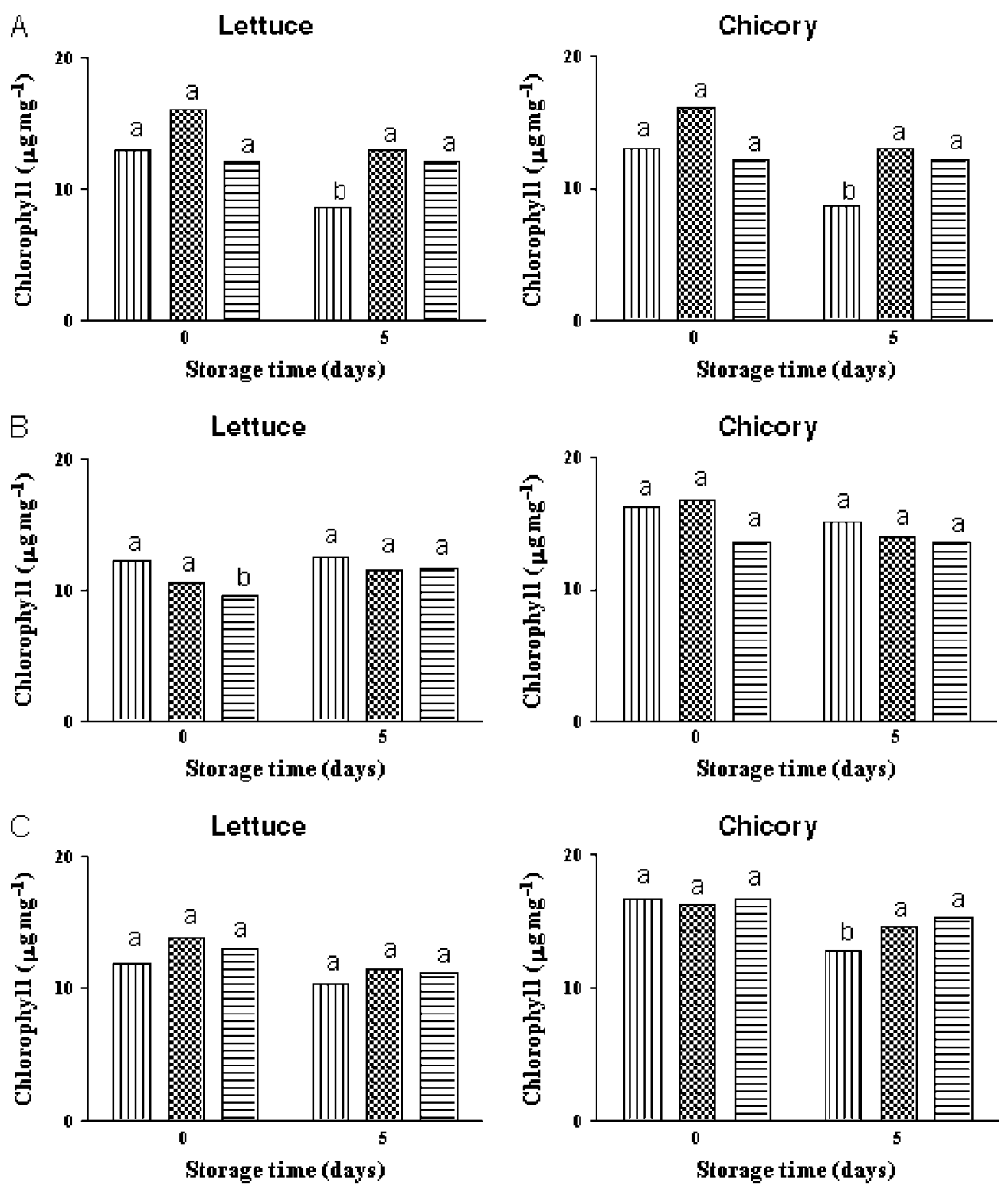

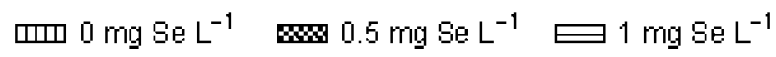

Figure 1. Chlorophyll content, measured at harvest and after storage $\left(5 \mathrm{~d}, 4^{\circ} \mathrm{C}\right)$, in leaves of lettuce and chicory plants subjected to different Se treatments, in different growing seasons (A, autumn; B, winter; C, spring). Values followed by different letters differ significantly at the $5 \%$ level by L.S.D. test.

In the spring experiment the PAL activity showed lower values compared to the winter experiment (data not shown). The enzyme activity at harvest was significantly decreased by the highest dose of Se only in lettuce. After a 5 day storage, no differences were detected among treatments either in lettuce and chicory.

\section{Ethylene production}

Our results showed that Se treatments lowered the ethylene production at harvest time in all cultivation periods both in lettuce and in chicory (Fig. 2). Ethylene production in lettuce was related to the cultivation season: the highest values were observed in autumn (Fig. 2A), and the lowest in spring (Fig. 2C). In chicory the seasonal variation of the ethylene production was less marked. In general, chicory showed a lower ethylene production compared to lettuce.
After a 5 day storage, the highest Se treatment induced a lower ethylene production in lettuce plants compared to controls in all the experiments performed (Fig. 2).

In chicory the storage did not lead to any significant differences in ethylene production compared to the harvest, except for the control plants, which showed a slight decrease in ethylene production in the winter experiment (Fig 2B), and an increase in the spring experiment (Fig. 2C).

\section{Ethylene accumulation in boxes during storage}

Ethylene concentrations in the atmosphere inside the package increased during the 5 day storage in all our experiments (Fig. 3). In autumn, ethylene production after 1 day was lower in lettuce

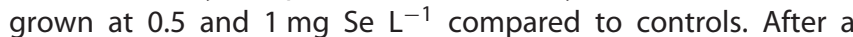
5 day storage, lettuce grown with 0 (control) and 0.5 Se mg 

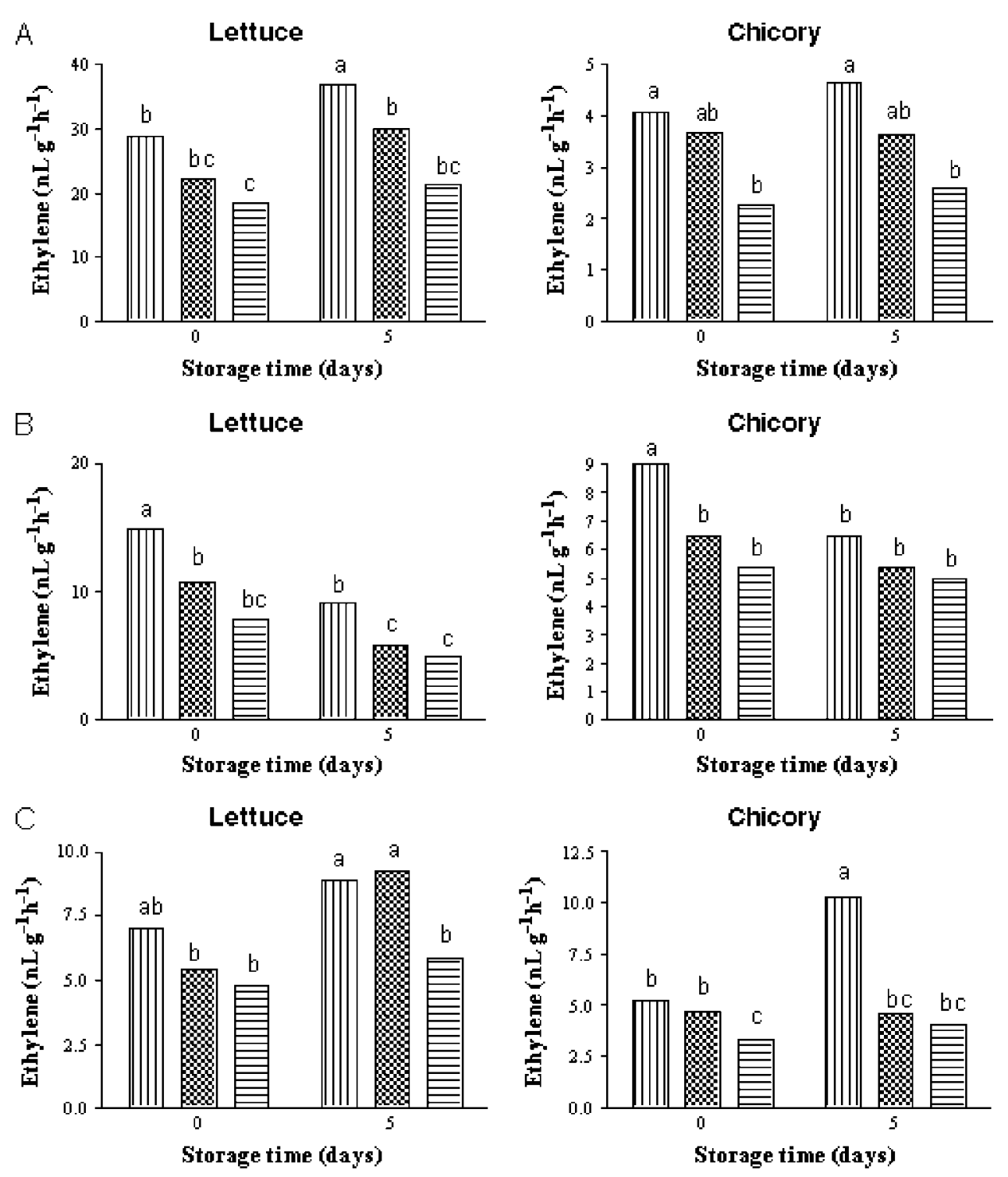

س山 $0 \mathrm{mg} \mathrm{L}^{-1} \mathrm{Se} \quad \& 0.5 \mathrm{mg} \mathrm{L}^{-1} \mathrm{Se} \quad \mathrm{E}_{1} 1 \mathrm{mg} \mathrm{L}^{-1} \mathrm{Be}$

Figure 2. Ethylene production, measured at harvest and after storage $\left(5 \mathrm{~d}, 4^{\circ} \mathrm{C}\right)$, in leaves of lettuce and chicory plants subjected to different Se treatments, in different growing seasons (A, autumn; B, winter; C, spring). Values followed by different letters differ significantly at the $5 \%$ level by L.S.D. test.

$\mathrm{L}^{-1}$ showed the same ethylene concentrations, while packages

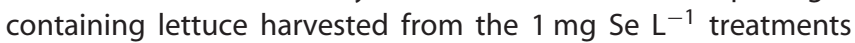
showed about $75 \%$ lower amounts (Fig. 3A). In winter the effect of Se was more marked. Both Se concentrations applied in the nutrient solution affected ethylene accumulation in the packages during storage (Fig. 3B). After a 5 day storage, packages

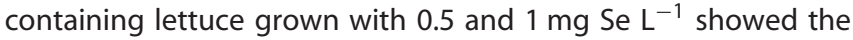
same amount of ethylene, almost half the amount compared to controls.

In spring the effect of treatments was not significant, though

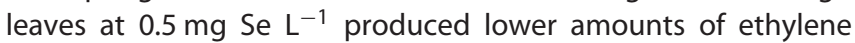
in the packages compared to controls and $1 \mathrm{mg}$ Se $\mathrm{L}^{-1}$ (Fig. 3C).

In chicory the Se treatments had a positive effect on post-harvest ethylene accumulation only in the autumn experiments (Fig. 3A). The ethylene concentration inside the packages was $0.3 \mathrm{~nL} \mathrm{~mL}-1$ (on average) compared to $0.5-0.7 \mathrm{~nL} \mathrm{~mL}^{-1}$ found in the control. In winter and spring no differences were found after 1 day storage, whereas higher ethylene concentrations were detected after 5 day storage in packages containing chicory leaves grown in Se added nutrient solutions (Fig. 3B and C)

\section{Nitrate content}

In lettuce the addition of Se to the nutrient solution led to an increase in the leaf nitrate content in the plants grown in the autumn and winter experiments (Table 4). On the other hand, in the spring experiment no differences were detected among controls and plants grown with $0.5 \mathrm{mg} \mathrm{Se}^{-1}$, and the highest dose of Se actually decreased the nitrate content.

In chicory the addition of Se increased the nitrate content only in the autumn experiment (Table 4). No differences were detected among controls and treated plants in the winter experiment. A decrease in nitrate content was detected in the spring experiment at the highest Se dose. 

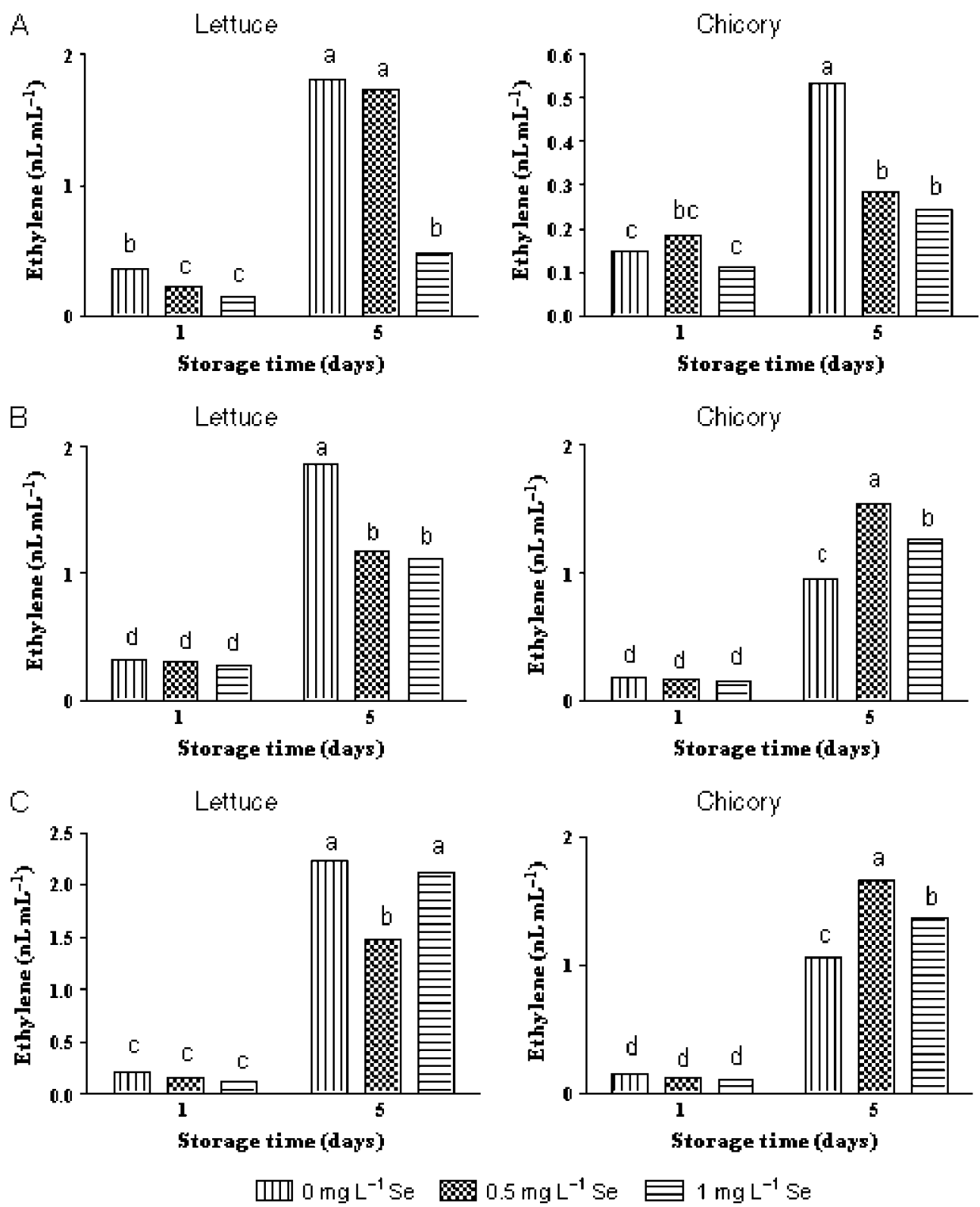

Figure 3. Ethylene accumulation measured after one and five storage days $\left(4^{\circ} \mathrm{C}\right)$ in boxes containing lettuce and chicory leaves subjected to different Se treatments, in different growing seasons (A, autumn; B, winter; C, spring). Values followed by different letters differ significantly at the $5 \%$ level by L.S.D. test.

\section{Selenium content in leafy vegetables}

Leaf selenium content increased by increasing the Se concentration in the nutrient solution in both plant species (Fig. 4). In the autumn experiment chicory accumulated lower amounts of Se than lettuce (Fig. 4A), whereas in spring and winter chicory showed higher Se concentrations than lettuce (Fig. 4B and C).

The correlation analysis of the selenium concentrations in leaves and the ethylene evolution in boxes during storage was always negative and ranged between -0.76 and -0.89 in chicory, and between -0.72 and -0.98 in lettuce (data not shown).

The Se concentration was also expressed on a fresh weight basis in order to provide useful information on the daily intake for human diets (data not shown) and the trend was similar to the Se concentration expressed on a dry weight basis.

\section{DISCUSSION}

The addition of selenium to the nutrient solution of lettuce and chicory resulted in an increase in the selenium concentration in the leaves, which had a positive effect on the plant yield. Our results are consistent with those obtained in chicory where the application of $1 \mathrm{mg} \mathrm{Se} \mathrm{L}^{-1}$ as a spray treatment increased the plant yield. ${ }^{27}$ However, findings by Xue et al. ${ }^{28}$ showed an increased plant growth only in senescing lettuce and at a low selenium dosage (0.1 mg Se kg ${ }^{-1}$ soil). Higher Se dosage ( $1 \mathrm{mg} \mathrm{Se} \mathrm{kg}^{-1}$ soil) was toxic to young seedlings and decreased dry weight in senescing plants. The different results may be due to the different chemical forms of the Se supplied, i.e. $\mathrm{H}_{2} \mathrm{SeO}_{4}$ instead of $\mathrm{Na}_{2} \mathrm{SeO}_{4}$.

The increase in nitrate content observed in the selenium-treated plants in autumn could be related to the highest yields showed by both species. The growth rate, expressed as fresh matter 
Table 3. Phenylalanine ammonia-lyase (PAL) activity measured at harvest and after storage ( 5 days at $4^{\circ} \mathrm{C}$ ) in lettuce and chicory plants subjected to different Se treatments in the winter experiment

\begin{tabular}{|c|c|c|}
\hline Se added ( $\mathrm{mg} \mathrm{Se} \mathrm{L}^{-1}$ ) & Lettuce & Chicory \\
\hline \multicolumn{3}{|l|}{ Harvest } \\
\hline 0 & $274.9^{\mathrm{a}}$ & $225.4^{b c}$ \\
\hline 0.5 & $190.3^{b c}$ & $159.7^{c}$ \\
\hline 1 & $131.2^{c}$ & $128.1^{c}$ \\
\hline \multicolumn{3}{|l|}{ Five-day storage } \\
\hline 0 & $276.6^{a}$ & $468.6^{\mathrm{a}}$ \\
\hline 0.5 & $243.0^{\mathrm{a}}$ & $389.5^{\mathrm{a}}$ \\
\hline 1 & $239.8^{\mathrm{a}}$ & $337.2^{\mathrm{ab}}$ \\
\hline \multicolumn{3}{|l|}{ Significance } \\
\hline Se concentration $(A)$ & NS & NS \\
\hline Time storage $(B)$ & NS & $* *$ \\
\hline$A \times B$ & NS & NS \\
\hline
\end{tabular}

Table 4. Nitrate content $\left(\mathrm{mg} \mathrm{kg}^{-1} \mathrm{FW}\right)$ in lettuce and chicory plants subjected to different Se treatments

\begin{tabular}{lccr|} 
& \multicolumn{3}{c}{ Growing season } \\
\cline { 2 - 4 } Se added $\left(\mathrm{mg} \mathrm{Se} \mathrm{L}^{-1}\right)$ & Autumn & Winter & Spring \\
\hline Lettuce & $2860^{\mathrm{bc}}$ & $1192^{\mathrm{a}}$ & $1169^{\mathrm{c}}$ \\
0 & $2641^{\mathrm{c}}$ & $1571^{\mathrm{b}}$ & $1134^{\mathrm{cd}}$ \\
0.5 & $3336^{\mathrm{a}}$ & $1590^{\mathrm{b}}$ & $963^{\mathrm{d}}$ \\
1 & & & \\
Chicory & $2698^{\mathrm{c}}$ & $1790^{\mathrm{c}}$ & $1790^{\mathrm{a}}$ \\
0 & $3540^{\mathrm{a}}$ & $1618^{\mathrm{a}}$ & $1618^{\mathrm{ab}}$ \\
0.5 & $3006^{\mathrm{b}}$ & $1490^{\mathrm{b}}$ & $1490^{\mathrm{b}}$ \\
1 & & & \\
Significance & $*$ & $\mathrm{NS}$ & $* *$ \\
Se concentration $(A)$ & NS & NS & $* *$ \\
Species $(B)$ & $*$ & NS & NS \\
$A \times B$ & &
\end{tabular}

Each column was tested separately. Values followed by different letters differ significantly at the $5 \%$ level by the LSD test.

Significance level: ${ }^{*} P \leq 0.05 ;{ }^{* *} P \leq 0.01$; NS, not significant.

produced (g) per square metre per day (data not shown), in fact was higher in the treated plants than in the controls. The highest nitrate levels observed in autumn could be ascribed to the atypical climatic conditions observed in this period, characterised by a lower daily accumulated radiation $\left(3.0 \mathrm{MJ}\right.$ day $^{-1}$ ) and a higher mean air temperature $\left(20.3^{\circ} \mathrm{C}\right)$ compared to the winter conditions (3.5 $\mathrm{MJ}$ day $^{-1}$ and $14.5^{\circ} \mathrm{C}$ ). Nevertheless, the values of nitrate were always lower than the maximum level permitted by European legislation (Commission Regulation, EC No. 188/2006).

We evaluated the colour of leafy vegetables essentially by monitoring the chlorophyll content. This parameter is related to the visual appearance, an external quality of leafy vegetables, which may have a direct effect on how consumers rate them in terms of attractiveness. ${ }^{7}$ Selenium did not affect the chlorophyll
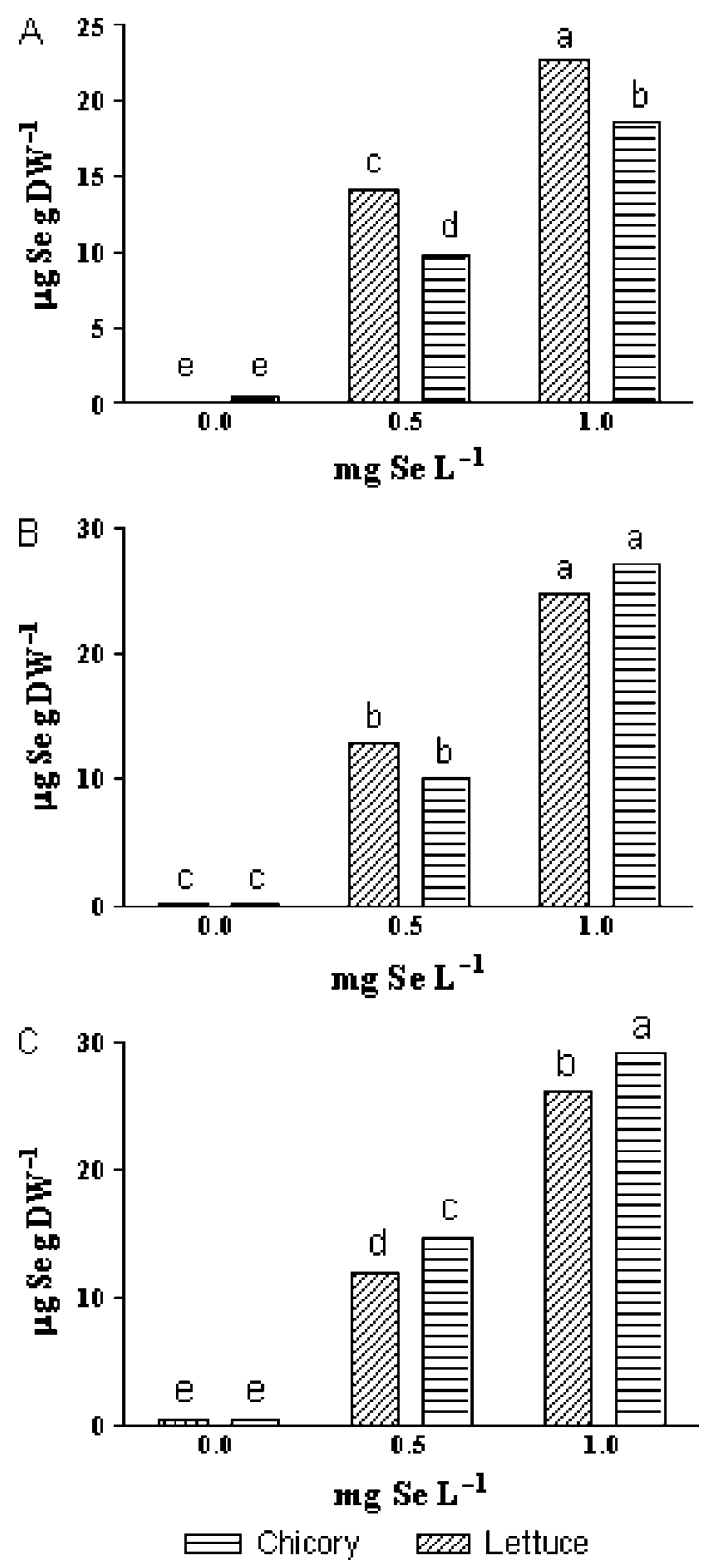

Figure 4. Selenium content measured at harvest in lettuce and chicory plants subjected to different Se treatments, in different growing seasons ( $A$, autumn; $B$, winter; $C$, spring). Values followed by different letters differ significantly at the $5 \%$ level by L.S.D. test.

degradation rate and thus the leaf senescence of chicory during storage. Only in lettuce was the addition of $0.5 \mathrm{mg} \mathrm{kg}^{-1}$ Se to the nutrient solution effective in preventing chlorophyll losses.

During post-harvest, ethylene production can reach high levels in the packages, depending on the packaging material and on its gas permeability, thus inducing senescence and quality losses. ${ }^{29}$ Ethylene also increases PAL activity and may dramatically increase tissue browning. Exposure of romaine lettuce to $10 \mu \mathrm{LL}^{-1}$ ethylene resulted in a strong increase in PAL activity. ${ }^{30}$ In our experiments selenium was generally effective in decreasing the production of ethylene, even though a seasonal effect seemed to be present.

It is well known that the biosynthesis of ethylene starts with methionine and ends with the oxidation of 1-aminocyclo-propane1-carboxylic acid (ACC). The first step of the entire pathway is characterised by the formation of S-adenosyl-methionine, which 
is converted to ACC, the immediate precursor of ethylene. ${ }^{31,32}$ Se in plants is incorporated into methionine and forms Se-methionine, ${ }^{33}$ thus reducing free methionine, which is the initial substrate of the ethylene biosynthesis pathway. This effect of Se on methionine may explain the lower ethylene production in the Se-enriched vegetables which, as a consequence, may have a longer shelf life and higher quality. The Se concentrations used in these experiments were in a range that does not induce physiological stress and phytotoxicity, and resulted in ethylene biosynthesis increases. ${ }^{34}$ In Spirulina platensis Se toxicity was observed in treatments higher than $40 \mathrm{mg} \mathrm{L}^{-1}$ when the chlorophyll content and biomass accumulation decreased. ${ }^{35}$

Our results indicated that selenium has a variable effect on PAL activity. On the surfaces of minimally processed vegetables, cut into small pieces and packed for storage or distribution, several physiological changes are induced by the wounds. The metabolic changes mainly affect ethylene production and the phenylpropanoids pathway whose first step is catalysed by PAL. An increase in PAL activity leads to an accumulation of soluble phenolic compounds, which are sequestrated in vacuoles, but the increase also generates browning reactions when membrane disruption occurs. ${ }^{1,36,37}$ The tissue browning is due to oxidative reactions of phenolic compounds by peroxidase and polyphenol oxidase. ${ }^{38}$ Therefore, the fact that lettuce is more sensitive to tissue browning ${ }^{6,39}$ than chicory could be explained by the higher ethylene production and PAL activity.

The recommended dietary allowance (RDA) for selenium is $55 \mu \mathrm{g}$ day $^{-1}$ for adults..$^{40}$ However, the German and Austrian Nutrition Society along with the Swiss Nutrition Association recommended an adequate daily intake for Se ranging from 30 to $70 \mu \mathrm{g} \mathrm{day}^{-1}$ for adult men and women. The tolerable dose for adults was set at $400 \mu \mathrm{g} \mathrm{day}^{-1} .^{40}$ Most EU countries have selenium dietary levels below the RDA guidelines. Our results showed that chicory and lettuce grown hydroponically with nutrient solutions containing $0.5 \mathrm{mg}$ Se $\mathrm{kg}^{-1}$ may provide a rational Se supplementation for human nutrition. In fact, $100 \mathrm{~g}$ of chicory gives $67 \mu \mathrm{g} \mathrm{Se}$, while lettuce gives $53 \mu \mathrm{g} \mathrm{Se}$, both in the optimal range for adult men and women, as reported by Reference Values for Nutrient Intake. ${ }^{40}$

In conclusion, our results suggest that the addition of $\mathrm{Se}$ in a nutrient solution can be a useful system for providing enriched leafy vegetables. In particular, a floating system can be used to modulate Se content in the nutrient solution and to grow vegetables with the optimal Se content for human health.

\section{ACKNOWLEDGEMENTS}

The authors would like to thank Irene Rosellini for her valuable technical assistance in the soil and plant analyses. This work was supported by MIUR within the Project 'Minimally processed horticultural products: production and quality improvement strategies' (2004-2005).

\section{REFERENCES}

1 Soliva-Fortuny RC and Martín-Belloso O, New advances in extending the shelf-life of fresh-cut fruits: a review. Trends Food Sci Tech 14:341-353 (2003).

2 Kumar N, Srivastava GC and Dixit K, Hormonal regulation of flower senescence in roses (Rosa hybrida L.). Plant Growth Regul 55:65-71 (2008).

3 Brecht JK, Saltveit ME, Talcott ST, Schneider KR, Felkey K and Bartz JA Fresh-cut vegetables and fruits. Hort Rev 30:185-246 (2004).

4 Martinez MV and Whitaker JR, The biochemistry and control of enzymatic browning. Trends Food Sci Tech 6:195-200 (1995).
5 Varoquaux $\mathrm{P}$ and Wiley RC, Biological and biochemical changes in minimally processed refrigerated fruits and vegetables, in Minimally Processed Refrigerated Fruits and Vegetables, ed. by Wiley RC. Chapman and Hall, New York, pp. 226-268 (1994).

6 Lopez-Galvez G, Saltveit ME and Cantwell M, Wound-induced phenylalanine ammonia lyase activity: Factors affecting its induction and correlation with the quality of minimally processed lettuce. Postharvest Biol Technol 9:223-233 (1996).

7 Ferrante A, Incrocci L, Maggini R, Serra G and Tognoni F, Colour changes of fresh-cut leafy vegetables during storage. J Food Agric Environ 2:40-44 (2004).

8 Biminger M, Pilawa S and Flohe L, Trends in selenium biochemistry. Nat Prod Rep 19:693-718 (2002).

9 Rotruck JT, Pope AL, Ganther HE, Swanson AB, Hafeman DG and Hoekstra WG, Selenium: biochemical role as a component of glutathione peroxidase. Science 179:588-590 (1973).

10 Pezzarossa B, Malorgio F and Tonutti P, Effects of selenium uptake by tomato plants on senescense, fruit ripening and ethylene evolution, in Biology and Biotechnology of the Plant Hormone Ethylene Il, ed. by Kanellis AK, Chang C, Klee H, Bleecker AB, Pech JC and Grierson D. Kluwer Academic Publishers, Dordrecht, pp. 275-276 (1999).

11 Hartman SC, Beelman RB and Simons S, Calcium and selenium enrichment during cultivation improves the quality and shelf life of Agaricus mushrooms, in Science and Cultivation of Edible Fungi, vols 1 and 2. A. A. Balkema, Rotterdam, Netherlands, pp. 499-505 (2000).

12 Zhang $\mathrm{M}$ and Ding $\mathrm{XL}$, Pigmental improvement of green vegetables by controlling free radicals during heat dehydration. Dry Technol 16:333-340 (1998).

13 Carvalho KM, Gallardo-Williams MT, Benson RF and Martin DF, Effects of selenium supplementation on four agricultural crops. J Agric Food Chem 51:704-709 (2003).

14 Finley JW, Increased intakes of selenium-enriched foods may benefit human health. J Sci Food Agric 87:1620-1629 (2007).

15 Min Z, Chunli L and Ping C, Effects of processing conditions of the green-leafy vegetable juice enriched with selenium on its quality stability. J Food Eng 62:393-398 (2004).

16 Pedrero Z, Madrid Y and Camara C, Selenium species bioaccessibility in enriched radish (Raphanus sativus): a potential dietary source of selenium. J Agric Food Chem 54:2412-2417 (2006).

17 Rios JJ, Rosales MA, Blasco B, Cervilla LM, Romero L and Ruiz JM, Biofortification of $\mathrm{Se}$ and induction of the antioxidant capacity in lettuce plants. Sci Hortic Amsterdam 116:248-255 (2008).

$18 \mathrm{Xu} \mathrm{J}$, Zhu S, Ynìng F, Cheng L, Hu Y, Pan G, et al, The influence of selenium on the antioxidant activity of green tea. J Sci Food Agric 83:451-455 (2003).

19 Xu GL, Hong SY, Song HB and Xie JK, Keshan disease and selenium deficiency. Nutr Res 1:187-192 (1985).

20 Slekovec M and Goessler W, Accumulation of selenium in natural plants and selenium supplemented vegetable and selenium speciation by HPLC-ICPMS. Chem Spec Bioavailability 17:63-73 (2005).

21 Lichtenthaler HK, Chlorophylls and carotenoids: pigments of photosynthetic membranes. Method Enzymol 148:350-382 (1987).

22 Welburn AR and Lichtenthaler $\mathrm{H}$, Formulae and program to determine carotenoids and chlorophyll $\mathrm{a}$ and $\mathrm{b}$ of leaf extracts in different solvents, in Advances in Photosynthesis Research, vol II, ed. by Sybesma C. Martinus Nijhoff/DrW Junk, The Hague, pp. 9-12 (1984).

23 Cheng GW and Breen PJ, Activity of phenylalanine ammonia-lyase (PAL) and concentrations of anthocyanins and phenolics in developing strawberry fruit. J Am Soc Hort Sci 116:865-869 (1991).

24 Castagna A, Ederli L, Pasqualini S, Mensuali-Sodi A, Baldan B, Donnini $S$, et al, The tomato ethylene receptor LE-ETR3 (NR) is not involved in mediating ozone sensitivity: causal relationships among ethylene emission, oxidative burst and tissue damage. New Phytologist 174:342-356 (2007).

25 Cataldo DA, Haroon M, Sehrader LE and Youngs VL, Rapid colorimetric determination of nitrate in plant tissue by titration of salicylic acid. Commun Soil Sci Plant Anal 6:71-80 (1975).

26 Zasoski RJ and Burau RG, A rapid nitric-perchloric acid digestion method for multi-elements tissue analysis. Commun Soil Sci Plan 8:425-436 (1977).

27 Germ M, Stibilj V, Osvald J and Kreft I, Effect of Selenium foliar application on chicory (Cichorium intybus L.). J Agric Food Chem 55:795-798 (2007). 
28 Xue $\mathrm{T}$, Hartikainen $\mathrm{H}$ and Piironen $\mathrm{V}$, Antioxidative and growthpromoting effect of selenium on senescing lettuce. Plant Soil 237:55-61 (2001).

29 Jiang WB, Sheng Q, Zhou XJ, Zhanga MJ and Xue-Jun L, Regulation of detached coriander leaf senescence by 1-methylcyclopropene and ethylene. Postharvest Biol Technol 26:339-345 (2002).

30 Ritenour MA and Saltveit, ME, Identification of a phenylalanine ammonia-lyase inactivating factor in harvested head lettuce (Lactuca sativa). Physiol Plant 97:327-331 (1996).

31 Adams DO and Yang SF, Ethylene biosynthesis: Identification of 1-aminocyclopropane-1-carboxylic acid as an intermediate in the conversion of methionine to ethylene. Proc Natl Acad Sci U S A 76:170-174 (1979).

32 Yang SF and Hoffman NE, Ethylene biosynthesis and action: A case of conservation. Plant Mol Biol 26:1579-1597 (1984).

33 Tapiero $\mathrm{H}$, Townsend DM and Tew KD, The antioxidant role of selenium and seleno-compounds. Biomed Pharmacother 57:134-144 (2003).

34 Tamaoki M, Freeman JL and Pilon-Smits EAH, Cooperative ethylene and jasmonic acid signaling regulates selenite resistance in Arabidopsis. Plant Physiol 146:1219-1230 (2008).
35 Chen TF, Zheng WJ, Wong YS and Yang F, Selenium-induced changes in activities of antioxidant enzymes and content of photosynthetic pigments in Spirulina platensis. J Integr Plant Biol 50:40-48 (2008).

36 Brecht JK, Physiology of lightly processed fruits and vegetables. HortScience 30:18-21 (1995).

37 Tomas-Barberan FA, Loaiza-Velarde J, Bonfanti A and Saltveit ME, Early wound- and ethylene-induced changes in phenylpropanoid metabolism in harvested lettuce. J Am Soc Hort Sci 122:399-404 (1997).

38 Saltveit ME, Effect of ethylene on quality of fresh fruits and vegetables. Postharvest Biol Technol 15:279-292 (1999).

39 Saltveit ME, Wound induced changes in phenolic metabolism and tissue browning are altered by heat shock. Postharvest Biol Technol 21:61-69 (2000).

40 Smrkolj P, Pograjc L, Hlastan-Ribi C and Stibilj V, Selenium content in selected Slovenian foodstuffs and estimated daily intakes of selenium. Food Chem 90:691-697 (2005). 